\title{
PENGEMBANGAN LEMBAR KERJA PESERTA DIDIK (LKPD) UNTUK MELATIHKAN KETERAMPILAN PROSES SAINS BERWAWASAN GREEN CHEMISTRY PADA MATERI ASAM BASA
}

\section{DEVELOPMENT OF STUDENT WORKSHEET TO PRACTICE THE SCIENCE PROCESS SKILLS WITH GREEN CHEMISTRY INSIGHT ON ACID BASE MATERIAL}

\author{
Suci Lailatul Fitriya dan*Mitarlis \\ Jurusan Kimia FMIPA Universitas Negeri Surabaya \\ e-mail: mitarlis@unesa.ac.id
}

\begin{abstract}
Abstrak
Penelitian ini bertujuan untuk mendeskripsikan kelayakan LKPD yang dikembangkan untuk melatihkan keterampilan proses sains berwawasan green chemistry pada materi asam basa. LKPD ini disusun berdasarkan komponen keterampilan proses sains, yang dilatihkan yaitu mengamati, membuat hipotesis, merencanaan penelitian, mengklasifikasi, menginterpretasi data dan menyusun kesimpulan. Prinsip green chemistry pada penelitian ini dibatasi hanya 3 prinsip yaitu prinsip no.1 tentang mencegah/mengurangi limbah, no.7 penggunaan bahan baku yang dapat diperbaharui dan no.12 mencegah/mengurangi terjadinya kecelakaan kerja. Rancangan penelitian ini menggunakan model 4-D (define, design, develop dan desseminate) namun, pada penelitian ini hanya dibatasi sampai tahap develop dan dilakukan uji terbatas terhadap 12 peserta didik kelas XI IPA SMA Negeri 14 Surabaya. Kelayakan LKPD yang dibahas meliputi: 1) validitas yang ditinjau dari validitas isi dan validitas konstruk, 2) kepraktisan yang ditinjau dari aktivitas peserta didik dan angket respon peserta didik, serta 3) keefektifan yang ditinjau dari tes keterampilan proses sains (pretest dan posttest). Hasil penelitian menunjukkan bahwa kelayakan LKPD ditinjau dari validitas isi dikatakan valid dengan persentase $80,36 \%$ dan validitas konstruk dalam kategori sangat valid dengan persentase rata-rata keseluruhan $83,89 \%$. Kepraktisan yang ditinjau dari aktivitas peserta didik dan respon peserta didik memperoleh hasil yang sangat praktis dengan presentase $90,28 \%$ dan $95,49 \%$. Keefektifan yang ditinjau dari hasil tes keterampilan proses sains mendapatkan $n$ gain score berkisar antara 0,66-0,88 dengan kategori sedang-tinggi sehingga pengembangan LKPD dikatakan layak untuk digunakan dalam pembelajaran.
\end{abstract}

Kata kunci: Lembar Kerja Peserta Didik (LKPD), Keterampilan Proses Sains, dan Green Chemistry.

\begin{abstract}
The aims of this study is describe developed worksheet to practice science process skills oriented green chemistry on acid base material. This worksheet was arranged based on the components of science process skills, mainly; doing observation, making hypotheses, planning research, classifying data, and making conclutions. The principles of green chemistry in this study were limited to 3 principles such as number 1 about waste prevention, number 7 about using of renewable feedstocks, and number 12 about conditioning for accident prevention. The design of this study is used a 4-D (define, design, develop and desseminate), however, this study is only limited to develop and conduct a limited test of 12 students of class XI IPA SMA 14 Surabaya. The feasibility of worksheet discussed includes: 1) validity in terms of content validity and construct validity, 2) practicality in terms of student activities and student questionnaire responses, and 3) effectivity in terms of science process skills tests (pretest and posttest). The results showed that the feasibility of worksheet in terms of content validity was said to be valid with a percentage of $80.36 \%$ and construct validity was said to be very valid with an overall average percentage of $83.89 \%$. Practicality in terms of student activities and student responses obtained very practical results with a percentage of $90.28 \%$ and $95.49 \%$. The effectiveness in terms of the results of the science process skills test got n-gain score ranging from 0.66-0.88 on the medium-high category so that the development of worksheet is feasible use in learning.
\end{abstract}

Key words: Student Worksheet, Science Process Skills, Green Chemistry 


\section{PENDAHULUAN}

Pembelajaran ilmu kimia pada kurikulum 2013 menuntut kesesuaian materi yang akan diajarkan dengan pengalaman atau contoh yang ada dalam kehidupan sehari-hari [1]. Kurikulum 2013 ditunjang dengan media yang salah satunya LKPD dan termasuk contoh sumber belajar sebagai media pada proses pembelajaran.

LKPD memuat lembaran yang berisikan tugas yang harus dikerjakan oleh peserta didik [2]. Isi dari LKPD setidaknya memuat judul, kompetensi dasar yang akan dicapai, waktu penyelesaian, peralatan/bahan yang diperlukan untuk menyelesaikan suatu tugas [3]. Hasil pra penelitian di SMA Negeri 14 Surabaya pada Oktober 2019 menunjukan bahwa 63,33\% LKPD yang digunakan belum menghubungkan materi yang dipelajari dengan kehidupan sekitarnya. Selain itu hanya berisikan soal-soal saja dan belum pernah menggunakan LKPD berbasis KPS karena masih terfokus pada tujuan belajar yang didominasi oleh pengetahuan konsep [4]. Pendekatan keterampilan proses sains merupakan pendekatan yang teratur untuk mempelajari informasi baru dan memecahkan masalah [5]. Hasil pra penelitiannya menunjukkan bahwa keterampilan proses sains mereka miliki lemah yaitu sebesar 76\% dengan kualifikasi mengajukan pertanyaan $18 \%$, merancang percobaan $20 \%$, menginterpretasi data $18 \%$ dan menganalisis data $18 \%$. Keterampilan proses sains sangat cocok jika dilatihkan pada saat pembelajaran dengan menggunakan praktikum.

Pembelajaran kimia merupakan pembelajaran yang membutuhkan kegiatan praktikum. Pembelajaran pada materi asam basa dapat dilatihkan KPS dan mampu membantu peserta didik untuk dapat memecahkan masalah terkait permasalahan yang ada pada kehidupan [6][7][8]. Peserta didik melaksanakan praktikum menggunakan bahan kimia berbahaya dilakukan tanpa memakai alat pelindung diri. Peserta didik belum mengetahui jenis bahan-bahan kimia yang akan digunakan pada saat praktikum seperti sifat bahan, bahaya dari bahan praktikum, arti simbol kimia, cara pemakaian alat pelindung diri, dan cara membuang limbah yang tepat [9]. Permasalahan tersebut jika dibiarkan begitu saja tentunya dapat membahayakan keselamatan praktikan, maka diperlukan praktikum yang aman dan ramah lingkungan dengan meminimalisir timbulnya limbah berbahaya serta mencegah atau mengurangi terjadinya kecelakaan di dalam pelaksanaan praktikum [9].

Prinsip green chemistry bila diterapkan pada kegiatan praktikum di dalam laboratorium akan mampu meminimalisir limbah hasil praktikum dan meningkatkan keselamatan kerja. [10]. Penerapan prinsip green chemistry dapat menjadi pendekatan yang penting dalam meningkatkan kesadaran peserta didik tentang masalah lingkungan [8]. Konsep green chemistry dapat diaplikasikan melalui pembelajaran kimia di sekolah khususnya dalam kegiatan praktikum [11][12]. Green chemistry ialah suatu konsep kimia inovatif yang mampu mengurangi penggunaan produksi bahan kimia berbahaya, pembuatan dan penggunaan produk kimia [13]. Tujuan keberlanjutan green chemistry untuk mengurangi limbah, meminimalkan penggunaan bahan berbahaya, mengurangi penggunaan energi serta sumber daya yang terbarukan, dan memaksimalkan penggunaan bahan dalam proses kimia [14][15]. Hasil angket pra penelitian yang dilakukan pada Oktober 2019 menunjukkan bahwa peserta didik belum pernah dikenalkan dengan green chemistry pada saat proses pembelajaran dan istilah green chemistry relatif baru sehingga peserta didik belum memahaminya dan berdasarkan hasil angket pra penelitian menunjukkan $96,67 \%$ peserta didik tidak mengetahui istilah green chemistry.

Berdasarkan permasalahan di atas, dapat dilakukan penelitian pengembangan LKPD untuk melatihkan keterampilan proses sains berwawasan green chemistry. Penelitian ini bertujuan untuk mengetahui kelayakan LKPD yang ditinjau dari 3 aspek yaitu validitas, kepraktisan dan keefektifan untuk melatihkan keterampilan proses sains berwawasan green chemistry pada materi asam basa.

\section{METODE}

Penelitian LKPD dilakukan dengan pengembangan model 4-D yang dikemukakan oleh Thiagarajan, Semmel dan Semmel dalam 
Ibrahim (2014) yang dipakai hanya 3 tahap, yaitu define, design, develop (uji coba terbatas) [16]. Penelitian diujikan di SMA Negeri 14 Surabaya kepada 12 peserta didik pada Februari 2020. Kelayakan perangkat dilihat dari 3 aspek yaitu validitas, kepraktisan serta keefektifan [17].

Kelayakan LKPD pada validitas dilihat dari validitas isi (kriteria isi) dan validitas konstruk (kriteria bahasa, kegrafisan dan penyajian). Validasi LKPD dinilai oleh 2 dosen kimia Unesa dan 1 guru kimia. Berikut tafsiran skala Likert dalam bentuk skor yang ditunjukkan Tabel 1 .

Tabel 1. Skor Skala Likert

\begin{tabular}{cc}
\hline Penilaian & Nilai Skala \\
\hline 0 & Kurang Baik Sekali \\
1 & Kurang Baik \\
2 & Cukup \\
3 & Baik \\
4 & Sangat Baik \\
\hline
\end{tabular}

[18].

Validitas LKPD untuk mengetahui kategori penilaiannya dihitung menggunakan rumus:

$$
\text { Persentase }(\%)=\frac{\text { Skor hasil yang didapat }}{\text { Skor kriteria }} \times 100 \%
$$

Persentase yang diperoleh dapat ditafsirkan dalam kategori Tabel 2.

Tabel 2. Tafsiran Kriteria Valid

\begin{tabular}{cc}
\hline Persentase (\%) & Kriteria \\
\hline $81-100$ & Sangat Valid \\
$61-80$ & Valid \\
$41-60$ & Cukup Valid \\
$21-40$ & Kurang Valid \\
$0-20$ & Kurang Valid Sekali \\
\hline
\end{tabular}

[18].

LKPD yang dikembangkan berdasar pada kriteria Tabel 2 layak digunakan jika persentase yang diperoleh $\geq 61 \%$.

Kelayakan LKPD pada kepraktisan dilihat dari aktivitas dan angket respon yang diisi pada saat pembelajaran berlangsung dan setelah memakai LKPD yang dikembangkan. Lembar aktivitas dan angket respon ini disusun dalam model pilihan "Ya" dan "Tidak" untuk jawabannya. Lembar aktivitas dinilai dengan memakai rumus:

$$
\mathrm{P}=\frac{f}{N} X 100 \%
$$

Keterangan:

$\mathrm{P}=$ Persentase jawaban peserta didik

$\mathrm{f}=$ Jumlah responden yang menjawab "Ya" untuk pertanyaan bersifat positif atau jumlah jawaban "Tidak" responden untuk pertanyaan bersifat negatif.

$\mathrm{N}=$ Jumlah peserta didik

Angket respon disusun 21 pertanyaan positif dan 3 pertanyaan negatif. Penilaiannya dihitung dengan skala Guttman yang ditunjukkan padaa Tabel 3.

Tabel 3. Kriteria Skala Guttman

\begin{tabular}{cccc}
\hline Jawaban & $\begin{array}{c}\text { Skor } \\
\text { Pertanyaan } \\
(+)\end{array}$ & Jawaban & $\begin{array}{c}\text { Skor } \\
\text { Pertanyaan } \\
(-)\end{array}$ \\
\hline Ya & 1 & Tidak & 1 \\
Tidak & 0 & Ya & 0 \\
\hline & & & \multicolumn{2}{c}{$[18]}$.
\end{tabular}

Angket respon dapat dihitung menggunakan rumus:

$$
\text { Persentase }(\%)=\frac{\text { Skor hasil yang didapat }}{\text { Skor kriteria }} \times 100 \%
$$

Persentase yang diperoleh ditafsirkan dalam kategori Tabel 4.

Tabel 4. Tafsiran Kriteria Praktis

\begin{tabular}{cc}
\hline Persentase (\%) & Kriteria \\
\hline $81-100$ & Sangat Praktis \\
$61-80$ & Praktis \\
$41-60$ & Cukup Praktis \\
$21-40$ & Kurang Praktis \\
$0-20$ & Kurang Praktis Sekali \\
\hline
\end{tabular}

LKPD yang telah dikembangkan dikatakan layak digunakan jika memperoleh respon positif $\geq 61 \%$ dari persebaran angket respon kepada peserta didik.

Kelayakan LKPD pada keefektifan dinilai dari pretest dan posttest keterampilan proses sains berwawasan green chemistry. Skor penilaiannya dapat dihitung memakai rumus:

Persentase $(\%)=\underline{\text { Skor hasil yang didapat }}$ Skor kriteria $\times 100 \%$

Pretest dan posttest yang mengalami peningkatan dianalisis dengan n-gain score. Skor yang diperoleh terlebih dahulu diuji menggunakan Kolmogrof, jika diperoleh $\alpha>0,5$ dikatakan data 
berdistribusi normal dan setelahnya dapat dicari perhitungannya memakai rumus:

$$
N \text {-gain score }=\frac{\text { Sposttest } \text {-Spretest }}{\text { Smaks-Spretest }}
$$

Peningkatan keterampilan proses sains berwawasan green chemistry peserta didik yang diperoleh ditafsirkan pada Tabel 5.

Tabel 5. Kategori Pengelompokkan $n$-gain score

\begin{tabular}{cc}
\hline Nilai & Kategori \\
\hline $\mathrm{g}<0,3$ & Rendah \\
$0,7>\mathrm{g}>0,3$ & Sedang \\
$\mathrm{g}>0,7$ & Tinggi
\end{tabular}

[19].

LKPD dikatakan layak digunakan jika pretest dan posttest memperoleh nilai $\geq 0,7$ atau $\geq 0,3$ dengan kriteria tinggi-cukup.

\section{HASIL DAN PEMBAHASAN}

Penelitian pengembangan berikut bertujuan membahas kelayakan LKPD yang dikembangkan. Penelitian dilaksanakan pada Februari 2020 di SMA Negeri 14 Surabaya kelas XI IPA 2. Berikut ialah uraian pengembangan model 4-D dalam Ibrahim (2014) yang akan dibahas pada tiap tahapannya, kecuali tahap desseminate.

\section{Tahap Define (Pendefinisian)}

Tahap define bertujuan sebagai penetapan dan pendefinisan syarat pada pembelajaran awalannya menganalisis tujuan dari batasan materi pada LKPD yang telah dikembangkan. Define memiliki 5 tahapan yaitu analisis kurikulum, analisis peserta didik, analisis tugas, analisis konsep, dan perumusan tujuan pembelajaran.

\section{Tahap Design (Perancangan)}

Tahap design bertujuan mempersiapkan prototipe perangkat pembelajaran. Kegiatan utama pada tahap design ialah penulisan dan pemilihan format LKPD yang berkaitan dengan materi asam basa, lalu dilanjutkan dengan perancangan LKPD. Hasil dari LKPD tersebut dikonsultasikan kepada dosen pembimbing.

LKPD ini memuat beberapa tahapantahapan pada keterampilan proses sains yang ditunjukkan pada Gambar 1 sampai 6.

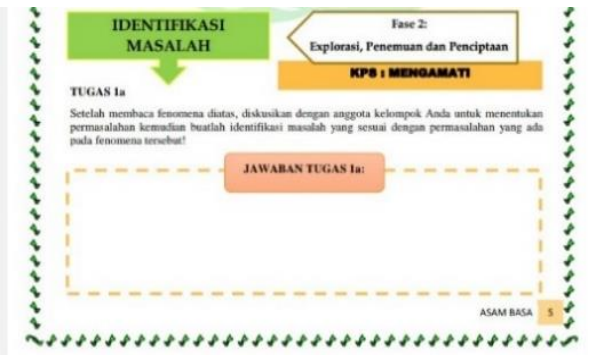

Gambar 1. Tampilan tahapan KPS mengamati pada LKPD

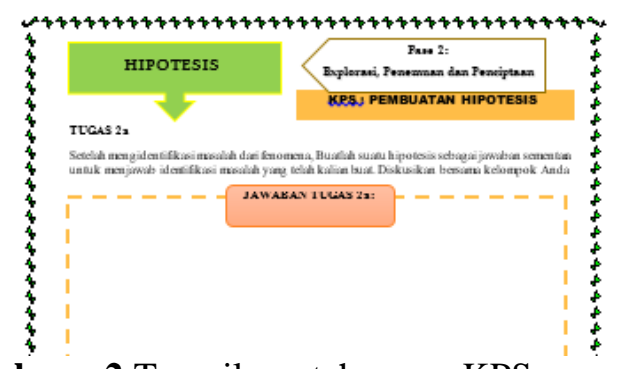

Gambar 2.Tampilan tahapan KPS membuat hipotesis pada LKPD

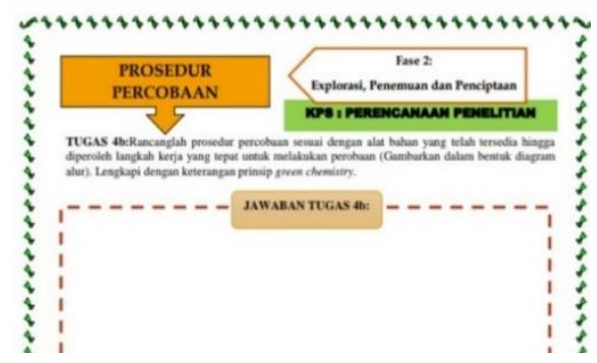

Gambar 3. Tampilan tahapan KPS perencanaan penelitian pada LKPD

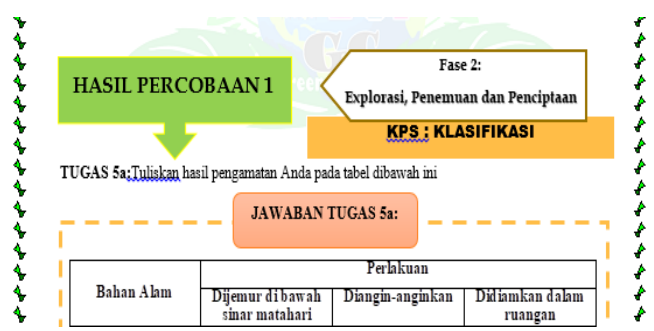

Gambar 4. Tampilan tahapan KPS klasifikasi pada LKPD

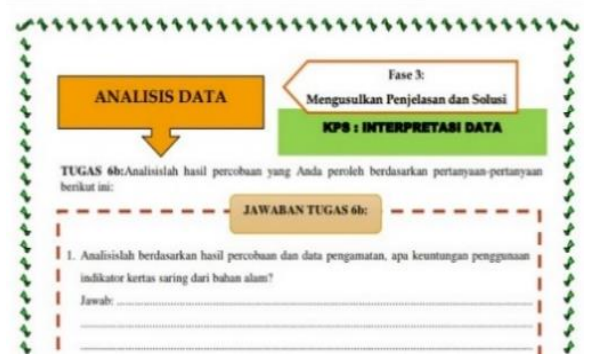

Gambar 5. Tampilan tahapan KPS interpretasi data pada LKPD 


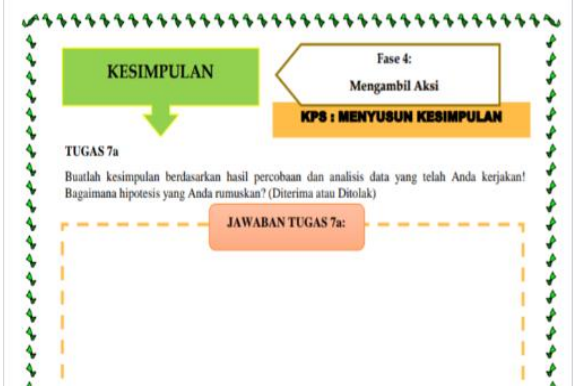

Gambar 6. Tampilan tahapan KPS menyusun kesimpulan pada LKPD

\section{Tahap Develop (Pengembangan)}

Tahap develop bertujuan menghasilkan perangkat pembelajaran yang telah direvisi berdasarkan masukan dosen kimia dan guru melalui validasi perangkat pembelajaran. Desain LKPD yang telah dibuat disebut sebagai draf I yang setelahnya akan ditelaah oleh dosen pembimbing agar mendapat kritik/saran sehingga dapat dilakukan revisi kembali yang nantinya akan menghasilkan draf II. Draf II selanjutnya diserahkan kepada pakar untuk divalidasi. LKPD yang telah divalidasi selanjutnya dilakukan revisi dan menghasilkan draf III, namun pada proses ini tidak perlu dilakukan validasi ulang sehingga hasil revisi dari draf II kemudian diujikan di SMA Negeri 14 Surabaya kepada 12 peserta didik yang dipilih secara acak selama $2 x$ pertemuan.

\section{Kelayakan LKPD}

Kelayakan LKPD ini ditinjau dari 3 aspek yang meliputi validitas dilihat dari validitas isi serta validitas konstruk. Kepraktisan dilihat dari aktivitas dan angket respon serta keefektifan diperoleh dari hasil pretest dan posttest keterampilan proses sains berwawasan green chemistry [17].

\section{Validitas LKPD}

Validitas LKPD didapatkan hasil dari para pakar yaitu 2 dosen kimia Unesa dan 1 guru kimia SMA Negeri 14 Surabaya melalui analisis lembar validasi diisi dengan mencetang nilai yang sesuai dengan kriteria dan rentang yang disajikan 0-4 [18]. Lembar validitas dilihat dari validitas isi meliputi kriteria isi dan validitas konstruk meliputi kriteria bahasa, kriteria kegrafisan, dan kriteria penyajian [2]. Hasil validasi LKPD ditampilkan pada Tabel 6.
Tabel 6. Data Hasil Validasi

\begin{tabular}{|c|c|c|c|}
\hline Validitas & Aspek & $\begin{array}{c}\text { Persentase } \\
(\%)\end{array}$ & Kriteria \\
\hline \multirow{2}{*}{$\begin{array}{c}\text { Validitas } \\
\text { Isi }\end{array}$} & Isi & 80,36 & Valid \\
\hline & Bahasa & 80,55 & Valid \\
\hline \multirow{4}{*}{$\begin{array}{l}\text { Validitas } \\
\text { Konstruk }\end{array}$} & Kegrafisan & 85 & Sangat \\
\hline & & & Valid \\
\hline & Penyajian & 86,11 & Sangat \\
\hline & & & Valid \\
\hline
\end{tabular}

Berdasarkan hasil pada Tabel 6 dapat diketahui bahwa LKPD yang dikembangkan telah valid karena semua kriteria memperoleh persentase $\geq 61 \%$ [20]. Validitas isi pada aspek kriteria isi mendapat persentase $80,36 \%$ dengan kategori valid dan dinyatakan layak yang ditinjau dari tercapainya standar isi [2]. Hal ini dikarenakan materi yang diberikan telah disesuaikan dengan Standar Kompetensi (SK) dan Kompetensi Dasar (KD) berdasar acuan kurikulum 2013. Validitas konstruk pada aspek bahasa mendapat persentase $80,55 \%$ dengan kategori valid dan dinyatakan layak berdasarkan tercapainya komponen kebahasaan [2]. Hal ini dikarenakan penggunaan bahasa pada LKPD yang dikembangkan sudah sesuai dengan tingkat kognitif peserta didik, dimana peserta didik SMA telah berada pada tingkat operasi formal sehingga mereka mampu menalar dan memahami makna abstrak dan prinsip-prinsip yang melandasi teori serta mengembangkan pemikiran peserta didik dalam memecahkan masalah [21].

Validitas konstruk pada aspek kegrafisan mendapat persentase $85 \%$ dengan kategori sangat valid dan dinyatakan layak berdasarkan komponen kegrafisan [2]. Hal ini dikarenakan dalam kriteria kegrafisan meliputi penggunaan font, tata letak, ilustrasi dan desain tampilan yang memudahkan peserta didik untuk membaca dan memahami materi [22]. Validitas konstruk pada aspek penyajian mendapat persentase $86,11 \%$ dengan kategori sangat valid dan dinyatakan layak berdasarkan komponen penyajian [2]. Hal ini dikarenakan kriteria penyajian pada LKPD telah memenuhi komponen yang baik diantaranya cover yang disajikan sesuai dengan isi LKPD, gambar dapat memotivasi peserta didik untuk memahami materi dan penggunaan warna yang kontras untuk 
meningkatkan daya tarik peserta didik [23]. Hasil ini diperkuat dengan penelitian Sholikhah yang menunjukkan bahwa kelayakan LKPD berdasarkan kriteria isi, bahasa, kegrafisan dan penyajian layak digunakan untuk melatihkan keterampilan proses sains dengan perolehan persentase berturut-turut $85,42 \%, 80,55 \%$, $81,66 \%$, dan $93,75 \%$ [23].

\section{Kepraktisan LKPD}

Kepraktisan LKPD diterima dari hasil observasi lembar aktivitas dan angket respon. Lembar observasi aktivitas dinilai pada saat proses pembelajaran berlangsung dan angket respon diperoleh dari hasil setelah menggunakan LKPD yang bagikan kepada 12 peserta didik. Lembar observasi aktivitas berisikan pertanyaan yang dilakukan selama peserta didik mengikuti pembelajaran berlangsung dan dilakukan selama $2 \mathrm{x}$ pertemuan. Hasil observasi lembar aktivitas bisa dilihat pada Gambar 7.

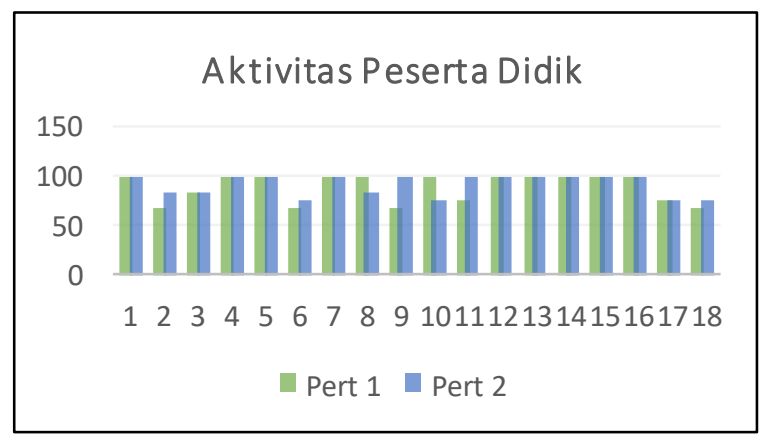

Gambar 7. Lembar Hasil Aktivitas

Berdasarkan hasil Gambar 7 pada pertemuan 1 sampai ke pertemuan 2 terjadi peningkatan. Hasil persentase rata-rata pada tiaptiap pertemuan ialah pertemuan ke-1 sebesar $88,89 \%$ dan pertemuan 2 sebesar 91,67\% sehingga diperoleh rata-rata 90,28\%. Aktivitas yang dilakukan yaitu melatihkan keterampilan proses sains berwawasan green chemistry, KPS yang dilatihkan pertama mengamati fenomena yang disajikan di dalam LKPD. Peserta didik setelah melakukan pengamatan diminta untuk menuliskan hasil pengamatannya pada LKPD tahap identifikasi masalah, selanjutnya peserta didik diminta untuk membuat hipotesis berdasarkan identifikasi masalah dengan membuat jawaban sementara terkait dengan fenomena. Peserta didik setelah membuat hipotesis diminta untuk merencanakan percobaan dengan menuliskan alur percobaan dalam bentuk diagram alur dengan dilengkapi prinsip green chemistry. Pembelajaran kimia dapat ditunjang dengan beberapa prinsip green chemistry antara lain pencegahan limbah, efisiensi energi, penggunaan bahan baku terbarukan, mendesain zat kimia dan produk yang mampu terurai setelah digunakan, menganalisa untuk mencegah polusi, menciptakan kondisi yang aman dalam bahan kimia untuk mencegah terjadinya kecelakaan kerja [24].

Prinsip green chemistry yang dilatihkan hanya di batasi 3 yaitu prinsip nomor 1 tentang mencegah/mengurangi limbah dengan contoh aplikasi mengurangi pemakaian tissue dan digantikan dengan lap agar limbah yang dihasilkan tidak terlalu banyak, pengurangan takaran pada bahan kimia agar limbah yang didapatkan sedikit dan tidak mencemari lingkungan. Prinsip nomor 7 tentang menggunakan bahan baku yang dapat diperbaharui dengan contoh aplikasi tanaman/bunga yang dapat ditanam kembali ketika habis dan tumbuhnya relatif cepat sehingga mampu digunakan sebagai indikator asam basa secara berkelanjutan. Bunga berwarna dalam penelitian diidentifikasi dan mampu untuk dimanfaatkan sebagai indikator asam basa antara lain bunga pacar air dan ruellia [25]. Prinsip nomor 12 tentang mencegah/mengurangi kecelakaan kerja dengan contoh aplikasi menggunakan pelarut/bahan kimia yang aman akan mengurangi terjadinya kecelakaan kerja. Peserta didik setelah menuliskan alur dalam bentuk diagram alur yang dilengkapi dengan prinsip green chemistry selanjutnya melakukan percobaan dan menuliskan hasil percobaan pada tahap klasifikasi dan sudah disediakan dalam bentuk tabel. Peserta didik setelah menuliskan hasil klasifikasi diminta untuk menjawab soal-soal yang ada pada LKPD di tahap interpretasi data, setelah menjawab soal peserta didik diminta untuk menuliskan hasil kesimpulan.

Angket respon dalam hal ini terdiri dari 24 butir dimana 21 pertanyaan bersifat positif dan 3 pertanyaan bersifat negatif yang dimuat dalam model pilihan Ya" dan "Tidak" untuk 
jawabannya. Angket respon menunjang kriteria isi, bahasa, kegrafisan dan penyajian berdasarkan LKPD yang dikembangkan. Hasil respon ditampilkan pada Gambar 8.

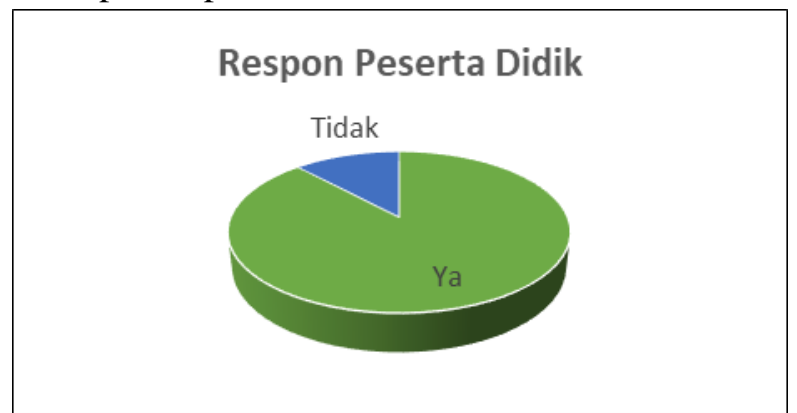

Gambar 8. Hasil Respon Peserta Didik

Berdasarkan Gambar 8 menunjukkan angket respon di peroleh persentase rata-rata ialah 95,49\% kategori sangat praktis. Berdasarkan uraian lembar observasi aktivitas dan angket respon menunjukkan hasil LKPD yang telah dikembangkan layak diterapkan karena mendapatkan persentase hasil $\geq 61 \%$.

\section{Keefektifan LKPD}

Keefektifan LKPD dihasilkan dari pretest dan posttest yang diberikan kepada peserta didik untuk menguji penguasaan terhadap LKPD yang telah dilatihkan dengan wawasan green chemistry dalam materi asam basa dengan menggunakan intrumen tes essay yang terdiri dari 7 soal [26][27]. Hasil pre dan post keterampilan proses sains berwawasan green chemistry ditunjukkan pada Tabel 7.

Tabel 7. Data Hasil Pretest dan Posttest

\begin{tabular}{cccccc}
\hline \multirow{2}{*}{ No } & \multirow{2}{*}{ Nama } & \multicolumn{2}{c}{ Nilai } & \multicolumn{2}{c}{ Gain-Score } \\
\cline { 3 - 6 } & & Pretest & Posttest & Gain & Kategori \\
\hline 1 & RHD & 16 & 90 & 0,88 & Tinggi \\
2 & MRT & 24 & 75 & 0,67 & Sedang \\
3 & MR & 24 & 86 & 0,81 & Tinggi \\
4 & EZK & 35 & 86 & 0,78 & Tinggi \\
5 & DIS & 37 & 86 & 0,77 & Tinggi \\
6 & CMP & 37 & 90 & 0,84 & Tinggi \\
7 & AF & 31 & 78 & 0,68 & Sedang \\
8 & TSK & 20 & 75 & 0,68 & Sedang \\
9 & ER & 35 & 78 & 0,66 & Sedang \\
10 & NPK & 18 & 75 & 0,69 & Sedang \\
11 & SAM & 2 & 75 & 0,74 & Tinggi \\
12 & SA & 12 & 75 & 0,71 & Tinggi \\
\hline
\end{tabular}

Berdasarkan Tabel 7 hasil nilai pretest dan posttest menunjukkan bahwa terjadi peningkatan lebih baik secara signifikan [28]. Nilai pretest rendah disebabkan karena peserta didik sama sekali belum pernah mendapatkan soal yang disertai komponen KPS berwawasan green chemistry. Keterampilan proses sains yang dimiliki peserta didik terjadi peningkatan hasil posttest setelah menggunakna LKPD yang dikembangkan saat pembelajaran. Berdasarkan pretest dan posttest yang diperoleh keterampilan proses sains berwawasan green chemistry didapatkan n-gain score berkisar 0,66-0,88 dengan kategori sedang-tinggi. Keterampilan proses sains penting untuk dapat memberikan informasi dan pengetahuan baru melalui suatu pengalaman langsung kepada peserta didik [29]. Keterampilan yang diukur meliputi mengamati, membuat hipotesis, merencanakan percobaan, mengklasifikasi, menginterpretasi data dan membuat kesimpulan [30]. Hasil rekaptulasi tiaptiap komponen KPS disajikan pada Gambar 9.

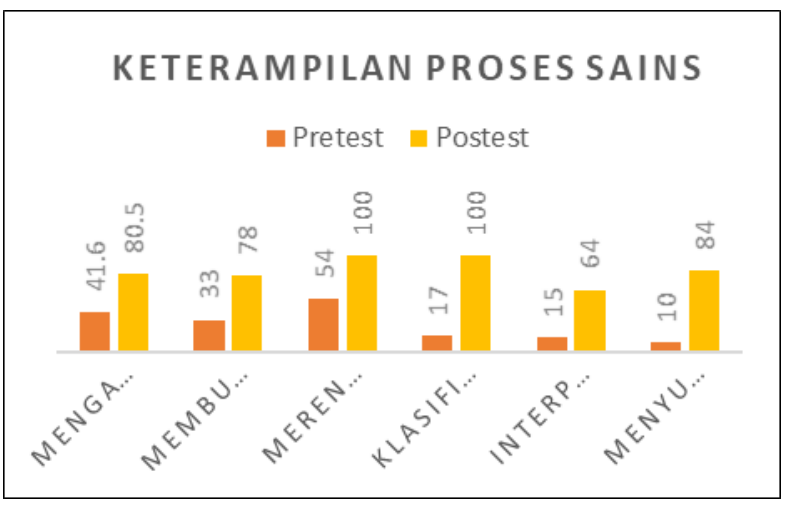

Gambar 9. Hasil Rekaptulasi KPS

Berdasarkan Gambar 9 komponen keterampilan proses sains terjadi kenaikan yang tidak begitu signifikan pada membuat hipotesis. Hal tersebut dikarenakan peserta didik belum bisa membuat jawaban sementara terkait dengan rumusan masalah yang telah diibuat dan keterampilan membuat hipotesis sulit dilakukan karena merupakan aspek yang menuntut untuk berfikir tingkat tinggi [30]. Peserta didik bisa membuat jawaban sementara saat sudah melakukan praktikum. Hal lainnya yang mempengaruhi rendahnya membuat hipotesis bisa dikarenakan peserta didik belum mengetahui cara menuliskan prediksi, tidak mengetahui apa yang akan diselidiki, dan kurang percaya diri dengan 
dugaan sementara yang dibuat [31]. Keterampilan proses sains yang lainnya sudah dirasa bagus untuk dilatihkan kepada peserta didik karena mengalami kenaikan yang signifikan. Penelitian di sekolah menengah Ramwittaya di Thailand mereka juga memperoleh rata-rata $74,52 \%$ dalam keterampilan proses sains dengan kategori tingkat baik [32]. Berdasarkan hasil dari Tabel 7 dan Gambar 9 bisa diketahui bahwa tiap komponen KPS terjadi kenaikan dengan perolehan $n$-gain score berkisar 0,66-0,88 yang memiliki kategori sedang-tinggi, bisa disimpulkan bahwa LKPD untuk melatihkan KPS berwawasan green chemistry pada materi asam basa dinyatakan layak digunakan. Hal ini didukung dengan hasil penelitian Suyono dan Rahmatillah dimana LKPD keterampilan proses sains memiliki dampak positif untuk melatihkan KPS berwawasan green chemistry pada materi asam basa layak diterapkan di SMA/MA [33][34].

\section{SIMPULAN}

Berdasarkan hasil penelitian dan pembahasan kelayakan yang ditinjau dari aspek validitas, kepraktisan, dan keefektifan dapat disimpulkan bahwa:

1. Validitas LKPD untuk melatihkan keterampilan proses sains berwawasan green chemistry pada materi asam basa dinyatakan layak digunakan ditinjau dari aspek validitas isi dan validitas konstruk. Persentase yang didapatkan pada tiap-tiap aspek validitas isi sebanyak $80,36 \%$ dengan kategori valid dan validitas konstruk sebanyak $83,89 \%$ dengan kategori sangat valid.

2. Kepraktisan LKPD untuk melatihkan keterampilan proses sains berwawasan green chemistry pada materi asam basa dinyatakan layak digunakan ditinjau dari observasi aktivitas peserta didik dan angket respon peserta didik setelah menggunakan LKPD. Persentase rata-rata hasil observasi peserta didik sebesar 90,28\% dengan kategori sangat praktis dan angket respon peserta didik sebesar 95,49\% dengan kategori sangat praktis.

3. Keefektifan LKPD untuk melatihkan keterampilan proses sains berwawasan green chemistry pada materi asam basa dinyatakan layak digunakan ditinjau dari hasil pretest dan posttest keterampilan proses sains. Hasil pretest dan posttest menunjukkan peningkatan pada peserta didik dan mendapatkan $n$-gain score berkisar 0,66-0,88 kategori sedang-tinggi.

\section{SARAN}

Analisis data \& hasil serta simpulan diajukan beberapa saran berikut ini:

1. LKPD yang dikembangkan bisa menggunakan materi lain dengan dilatihkan keterampilan proses sains berwawasan green chemistry.

2. Keterampilan yang dilatihkan kepada peserta didik tidak hanya yang kembangkan peneliti, bisa mengembangkan keterampilan yang lainnya dengan diberikan wawasan green chemistry.

3. Penerapan prinsip green chemistry yang dikembangkan tidak hanya yang sudah dikembangkan peneliti, bisa mengembangkan prinsip-prinsip green chemistry yang lainnya.

\section{DAFTAR PUSTAKA}

1. Semiawan, C. 1992. Pendekatan Keterampilan Proses. Jakarta: Gramedia Sanjaya.

2. Depdiknas. 2008. Panduan Pengembangan Bahan Ajar. Jakarta: Departemen Pendidikan Nasional Direktorat Jenderal Manajemen Pendidikan Dasar dan Menengah Direktorat Pembinaan Sekolah Menengah Atas.

3. Prastowo, A. 2012. Panduan Kreatif Membuat Bahan Ajar Inovatif Menciptakan Metode yang Pembelajaran Menarik dan Menyenangkan. Yogyakarta: DIVA Press.

4. Diella, D., Ahmad, R., \& Suhedi, H, Y. 2019. Pelatihan Pengembangan LKPD Berbasis Keterampilan Proses Sains (KPS) dan Penyusunan Instrumen Asesmen KPS Bagi Guru IPA. Jurnal Publikasi Pendidikan. Vol.9, No.1.

5. Nur, M. 2011. Modul Keterampilanketerampilan Proses Sains. Surabaya: Pusat Sains dan Matematika Sekolah Unesa.

6. Mulda, A. D. 2018. Development of Student Worksheets Based On Science Process Skills 
In Biology Learning. Prociding National of Biology. Hal.132-135.

7. Djamarah, S. B., \& Zain, A. 2010. Strategi Belajar Mengajar. Jakarta: Rineka Cipta.

8. Chen, T. L., Kim, H., Pan, S. Y., Tseng, P. C., Lin, Y. P., \& Chiang, P. C. 2020. Implementation of Green Chemistry Principles In Circular Economy System Toward Sustainable Development Goals: Challenges and Perspectives. Journal Pre-proof.

9. Azizah, U. 2017. Pengembangan Buku Petunjuk Praktikum Bernuansa Green Chemistry Pada Materi Asam Basa, Larutan Penyangga, dan Hidrolisis Garam Kelas XI $S M A$. Semarang: Universitas Islam Negeri Walisongo.

10. Nurbaity. 2011. Pendekatan Green Chemistry Suatu Inovasi Dalam Pembelajaran Kimia Berwawasan Lingkungan. Jurnal Riset Pendidikan Kimia. Vol.1, No.1.

11.Nuswowati, M., Sulisianingsih, E., Ramlawati., \& Kadarwati, S. 2017. Implementation of Problem-Based Learning With Green Chemistry Vision To Improve Creative Thinking Skills And Students Creative Actions. Jurnal Pendidikan IPA Indonesia. Vol.6, No.2, Hal.221-228.

12. Listyarini, R. V., Pamenang, F. D. N., Harta., Wijayanti, L. W., Asy'ari, M., \& Lee, W. 2019. The Integration Of Green Chemistry Principles Into Small Scale Chemistry Practicum For Senior High School Students. Jurnal Pendidikan IPA Indonesia. Vol.8, No.3, Hal.371-378.

13. P. T. Anastas., \& J. C. Warner. 1998. Green Chemistry: Theory and Practice. New York: Oxford University Press. By permission of Oxford University Press.

14.Ming H., Uyo, K., Yong S., P, Daniel., \& Lin, C. S. K. 2019. Recent Trends In Green And Sustainable Chemistry: Rethinking Textile Waste In A Circular Economy. International Journal of Instruction. No.20, Hal.1-10.

15.Marco. B. A., Rechelo, B. S., Totoli, E. G., Kogawa, A. C., \& Salgado, H. R. N. 2019. Evolution of Green Chemistry and Its Multidimensional Impacts: A Review. Saudi Pharmaceutical Journal. No.27, Hal.1-8.

16.Ibrahim, M. 2014. Model Pemeblajaran Inovatif melalui Pemaknaan. Surabaya: Unesa Press.
17.Sinaga, D. D., Nyeneng, I. D. P., \& Herlina, K. 2019. Pengembangan Lembar Kerja Peserta Didik Berbasis Predict-Observe-Explain Pada Materi Tekanan Dalam Zat Cair Untuk Meningkatkan Keterampilan Sains Siswa. Jurnal Pendidikan Fisika. Vol.2, No.2.

18.Riduwan. 2015. Skala Pengukuran VariabelVariabel Penelitian.Bandung: Alfabeta.

19.Hake, R. R. 1998. Interactive Engagement Versus Traditional Methods: A Six Thousand Student Survey of Mechanics Test Dara for Introductory Physics Courses. American Journal Physics. Vol.66, No.1, Hal.64-74.

20.Sugiyono. 2012. Metode Penelitian Pendidikan Pendekatan Kuantitatif dan $R \& D$. Bandung: Alfabeta.

21.Sanjaya, W. 2008. Strategi Pembelajaran Berorientasi Standar Proses Pendidikan. Jakarta: Kencana Prenada Media.

22.Suharyadi, P., Anna., \& Hernani. 2013. Pengembangan Buku Bahan Ajar Berbasis Kontekstual Pada Pokok Bahasan Asam Basa. Jurnal Riset dan Praktik Pendidikan. Vol.1, No.1.

23.Sholikhah, M. 2017. Pengembangan Lembar Kerja Peserta Didik Berbasis Problem Solving Untuk Melatihkan Keterampilan Proses Sains Pada Materi Asam Basa. Surabaya: Jurusan Kimia Unesa.

24.Mitarlis., Azizah, U., \& Yonata, B. 2018. Alternative Lesson Design of Basic Chemistry Learning To Integrate Green Chemistry Principles As View of Scientific Character Values. Advances in Engineering Research. Vol.171.

25.Mitarlis., Azizah, U., \& Yonata, B. 2018. Pemanfaatan Indikator Alam dalam Mewujudkan Pembelajaran Kimia Berwawasan Green Chemistry. Jurnal Penelitian Pendidikan IPA. Vol.3, No.1.

26.Yustiqvar, M., Hamzah, S., \& Gunawan, G. 2019. Analisis Penguasaan Konsep Siswa Yang Belajar Kimia Menggunakan Multimedia Interaktif Berbasis Green Chemistry. Jurnal Pijar MIPA. Vol.14, No.3, Hal.135-140.

27.Lestari, M. Y., \& Diana, N. 2018. Keterampilan Proses Sains (KPS) Pada Pelaksanaan Praktikum Fisika Dasar I. Indonesian Journal of Science and Mathematics Education. Vol.1, No.1, Hal.4954. 
28.Marsia., Dahlan., \& Tirani, Y. 2019. Penerapan Pendekatan Keterampilan Proses Sains Untuk Meningkatkan Hasil Belajar Siswa Kelas XI Pada Pokok Bahasan Larutan Asam Basa. Jurnal Pendidikan Kimia FKIP Universitas HaluOleo. Vol.4, No.3, Hal.200210.

29.Sarah, N., Andi, M., \& Agung, S. 2019. Pengembangan Bahan Ajar Model Penemuan Terbimbing Untuk Melatih Keterampilan Proses Sains Peserta Didik. Jurnal Ilmiah Pendidikan Fisika. Vol.3, No.3, Hal.104-116.

30.Juhji. 2016. Peningkatan Keterampilan Proses Sains Siswa Melalui Pendekatan Inkuiri Terbimbing. Jurnal Penelitian dan Pembelajaran IPA (JPPA). Vol.2, No.1, Hal.58-70.

31.Nurliani., Sartika, R., \& Hadi, L. 2018. Deskripsi Keterampilan Proses Sains Siswa Kelas XI IPA SMA Negeri 2 Sungai Raya
Pada Materi Asam Basa. Artikel penelitian. Vol.1, No.4, Hal.121-128.

32.Lati, W., Supasorn, S., \& Promarak, V. 2012. Enhancement of Learning Achievement And Integrated Science Process Skills Using Science Inquiry Learning Activities of Chemichal Reaction Rates. International Journal to Procedia-Social and Behaviour Science. Vol.2, No.3, Hal.4471-4475.

33.Suyono. 2019. Inkuiri Terbimbing Untuk Meningkatkan Keterampilan Proses Sains Siswa Sekolah Menengah Atas. Jurnal Komunikasi Pendidikan. Vol.3, No.2, Hal.8691.

34.Rahmatillah., Halim, A., \& Hasan, M. 2017. Pengembangan Lembar Kerja Peserta Didik Berbasis Keterampilan Proses Sains Terhadap Aktivitas Pada Materi Koloid. Jurnal Penelitian IPA dan Pembelajaran IPA (JIPI).Vol.1,No.2,Hal.121-130. 